\title{
The Effect of Epsilon Amino Caproic Acid and Other Inhibitors of Proteolysis Upon the Response of Human Peripheral Blood Lymphocytes to Phytohemagglutinin
}

\author{
Rochelle HirschHorn, Judith Grossman, Walter Troll, and \\ Gerald Weissmann \\ From the Departments of Medicine (Cell Biology and Genetics) and \\ Environmental Medicine, New York University School of Medicine, \\ New York 10016
}

\begin{abstract}
A в S T R A C T Previous work has suggested that intracellular proteolysis may play a role in lymphocyte stimulation. An inhibitor of proteolysis, epsilon amino caproic acid (EACA) was studied for its effect on the lymphocyte response to phytohemagglutinin (PHA). EACA was found to inhibit several parameters of lymphocyte stimulation (e.g. DNA, RNA, and protein synthesis as well as alterations in morphology) This inhibition was not due to diminished cellular viability and did not permanently impair the capacity of the lymphocyte to subsequently respond to PHA. Additionally, there was no evidence that this inhibition was due to other possible effects of EACA, such as alterations in $\mathrm{Na}^{+}-\mathrm{K}^{+}$transport, competitive amino acid deprivation or interference with PHA binding. Moreover, the inhibitors of proteolysis, tosyl arginine methyl ester (TAME), tosyl lysine chloromethyl ketone (TLCK), and tosyl phenylalanine chloromethyl ketone (TPCK), were also shown to inhibit lymphocyte stimulation.
\end{abstract}

EACA was most effective when added during the first $24 \mathrm{hr}$ of stimulation. Therefore; these experiments support the hypothesis that proteolysis is an essential step in the early phase of lymphocyte activation.

\section{INTRODUCTION}

The circulating human peripheral blood lymphocyte, when cultured in vitro, survives for a short period of time without undergoing morphologic alterations, ex-

Dr. Hirschhorn is Senior Investigator of the New York Heart Association, and Dr. Weissmann is Career Scientist 1-467 of the Health Research Council of the City of New York.

Received for publication 31 August 1970 and in revised form 14 January 1971. tensive synthesis of macromolecules, or mitosis. However, these cells can be stimulated to increase their synthesis of RNA, protein, and DNA. Morphologically, the cells become large, pyroninophilic cells with reticular chromatin; these changes are usually accompanied by mitosis. This stimulation can be brought about by several agents such as phytohemagglutinin (PHA), ${ }^{1}$ pokeweed mitogen (PWM), staphylococcal exotoxin, and a mitogen associated with streptolysin $\mathrm{S}$, all of which appear to affect the majority of cells, independent of their prior history. Stimulation can also be induced by antigens, in a limited number of cells, when these cells derive from a sensitized donor, or by foreign histocompatibility antigens (1-3).

Our previous studies have shown that nuclei isolated from PHA-stimulated lymphocytes have an increased capacity to prime for RNA synthesis in the presence of exogenous RNA polymerase (4); a finding which could be duplicated in vitro by exposing isolated nuclei to low concentrations of trypsin $(4,5)$. It was therefore postulated that proteolysis may have exposed, at least in part, new sites for RNA synthesis. In order to evaluate the possible role of intranuclear proteolysis in the observed increase in transcription we have examined the effects of protease inhibitors upon stimulation of lymphocytes induced by PHA.

Since previous work also suggested that intracellular redistribution of lysosomal enzymes is associated with

\footnotetext{
${ }^{1}$ Abbreviations used in this paper: EACA, epsilon amino caproic acid; FCS, fetal calf serum; MEMS, minimum essential medium spinner; PHA, phytohemagglutinin; PPL, protein polysaccharide light; PWM, pokeweed mitogen; TAME, tosyl arginine methyl ester; TCA, trichloracetic acid; TLCK, tosyl lysine chloromethyl ketone; TPCK, tosyl phenyl-alanine chloromethyl ketone.
} 
the early stages of lymphocyte stimulation (6-8), we have studied in detail one compound which has been shown to inhibit lysosomal proteases. Epsilon aminocaproic acid (EACA) is a synthetic lysine derivative, best known for its inhibition of plasminogen activation (9). Although epsilon aminocaproic acid is only a weak inhibitor of trypsin, and of plasmin itself $(10,11)$, it also inhibits to variable degrees the action of three lysosomal proteases: $(a)$ the acid protease-mediated breakdown of cartilage (12); (b) the degradation of PPL (protein polysaccharide light) by a lysosomal neutral protease (13); and (c) the release of arginine from histones at neutral $\mathrm{pH}$ by a lysosomal enzyme (14). The present study has demonstrated that EACA inhibits transformation of lymphocytes, as measured by several parameters. This action is apparently not due to an alteration of cellular viability or number, to an effect upon complement, potassium transport, or amino acid transport. Furthermore, the protease inhibitors tosyl arginine methyl ester (TAME), tosyl lysine chloromethyl ketone (TLCK), and tosyl phenylalanine chloromethyl ketone (TPCK), like EACA, effectively block lymphocyte transformation.

\section{METHODS}

Separation and culturing of cells. Human peripheral blood lymphocytes were obtained by methods previously described (15). Briefly, heparinized blood was sedimented spontaneously at $37^{\circ} \mathrm{C}$, the supernatant plasma was removed, treated with ADP to aggregate platelets, and passed through a prewarmed nylon fiber column at $37^{\circ} \mathrm{C}$ to remove phagocytic cells. The resulting lymphocyte suspension was washed three times, resuspended in complete media (minimum essential medium spinner [MEMS]), 20\% heat-inactivated FCS (fetal calf serum), $1 \% 200 \mathrm{~mm}$ glutamine, $100 \mathrm{U}$ penicillin, and $100 \mu \mathrm{g}$ streptomycin $/ \mathrm{ml}$ ) and the mixture was usually allowed to stand overnight at room temperature at a cell concentration of $5-10 \times 10^{6} / \mathrm{ml}$.

Culturing procedures. Cell suspensions were adjusted to concentrations of $7-9 \times 10^{5}$ cells $/ \mathrm{ml}$ of complete media, dispensed in $4 \mathrm{ml}$ portions into $15-\mathrm{ml}$ screw-top glass culture tubes $(16 \times 150 \mathrm{~mm})$, and incubated in a $37^{\circ} \mathrm{C}$ water bath for varying times. When rates of synthesis were measured during the first $3 \mathrm{hr}$ of culture, $20-\mathrm{ml}$ portions of cell suspension in $50 \mathrm{ml}$ Bellco screw-top tubes were used, and cultures were preincubated at $37^{\circ} \mathrm{C}$ overnight before the addition of phytohemagglutinin (PHA).

Cell counts and viability. White blood cell counts were determined by standard methods using a $1: 20$ dilution of cell suspension with $0.6 \%$ acetic acid containing methylene blue; cell counts from individual cultures were performed using a $1: 1$ dilution. Cell viability was determined after 5 min incubation in a $1: 1$ dilution of cell suspension with erythrosin B (Fisher Scientific Co. Pittsburgh, Pa.) in phosphate-buffered saline (final concentration of erythrosin $\mathrm{B}$ of $0.067 \mathrm{~g} \%$ ).

$D N A$ determination. Individual $4 \mathrm{ml}$ cultures were centrifuged at $1200 \mathrm{rpm}$ in an International PR 2 centrifuge (International Equipment Co; Needham Heights, Mass.), washed twice with normal saline, and the DNA content of the cell pellet was determined by the method of Burton (16) as utilized by Tedesco and Mellman (17). Preliminary experiments indicated that the quantity of RNA present did not significantly interfere with the determination of DNA content by this method. To determine this, cells were washed twice with saline and the cell pellet assayed for diphenylamine-reactive material after three different treatments. One portion was used directly for determination of DNA. In a second portion, the RNA was hydrolyzed with $0.5 \mathrm{ml}$ of $0.3 \mathrm{~N} \mathrm{KOH}$ at $37^{\circ} \mathrm{C}$ for $1 \mathrm{hr}$, and cooled to $0^{\circ} \mathrm{C}$ in ice and DNA was precipitated by the addition of 0.25 $\mathrm{ml}$ of $1.2 \mathrm{~N}$ perchloric acid. This precipitate was washed twice with cold $0.2 \mathrm{~N}$ perchloric acid and the DNA content was determined. A third portion was subjected to all the above wash procedures but the hydrolysis of RNA by $\mathrm{KOH}$ was omitted and addition of $0.75 \mathrm{ml}$ of $0.2 \mathrm{~N}$ perchloric acid at $0^{\circ} \mathrm{C}$ for $1 \mathrm{hr}$ was substituted. Cells which were precipitated and washed with perchloric acid (but not submitted to alkaline hydrolysis) yielded $92 \%$ of the "Burton-reactive material" found in cells simply washed twice with saline. RNA hydrolysis did not significantly alter this value, yielding $89 \%$ of "Burton-reactive material" found in salinewashed cells $(n=3)$. Therefore, all further determinations of DNA were performed without prior RNA hydrolysis.

\section{Determination of rates of macromolecular synthesis.}

DNA. Incorporation of thymidine ${ }^{14} \mathrm{C}(\mathrm{SA} \cong 53.8 \mathrm{mCi}$ / mmole) into trichloracetic acid (TCA)-precipitable material was used to measure rates of DNA synthesis. $0.3-0.45 \mu \mathrm{Ci}$ (as indicated) were added to $4-\mathrm{ml}$ cultures for $24 \mathrm{hr}$ periods, the cultures cooled to $4^{\circ} \mathrm{C}$, and centrifuged at 1200 $\mathrm{rpm}$. The cell pellet was washed twice in ice-cold normal saline, precipitated with ice-cold $15 \%$ TCA for $1 \mathrm{hr}$, centrifuged at $2000 \mathrm{rpm}$, and washed twice with $5 \mathrm{ml}$ portions of $15 \%$ ice cold TCA. The precipitate was then dissolved in $0.5 \mathrm{ml}$ hyamine by heating at $56^{\circ} \mathrm{C}$ for $\frac{1}{2}-1 \mathrm{hr}$, transferred with three $5-\mathrm{ml}$ portions of PPO-POPOP in toluene to counting vials and counted in a Packard Tri-Carb liquid scintillation counter with an efficiency of $75 \%$ for ${ }^{14} \mathrm{C}$. Cultures to which thymidine $-{ }^{14} \mathrm{C}$ was added just before harvesting contained less than 30-50 CPM's acid-insoluble counts.

RNA. Incorporation of uridine- ${ }^{14} \mathrm{C}$ (specific activity $\cong 54.5 \mathrm{mCi} / \mathrm{mmole}$ ) into acid-precipitable counts was used as a parameter of RNA synthesis. $1 \mu \mathrm{Ci} / 4 \mathrm{ml}$ culture was added for the last 2- or $3 \mathrm{hr}$, as indicated, before harvesting. The same harvest procedure as for DNA was utilized.

Protein. $2 \mu \mathrm{Ci}$ of leucine- ${ }^{14} \mathrm{C}$ ( $\mathrm{SA} \cong 160 \mathrm{mCi} / \mathrm{mmole}$ ) per $4 \mathrm{ml}$ culture were added for $3-4 \mathrm{hr}$ (as indicated) before harvesting. The cells were then centrifuged at $1200 \mathrm{rpm}$ at $4^{\circ} \mathrm{C}$, washed twice with cold normal saline, and $0.5 \mathrm{ml}$ of $1 \mathrm{~N} \mathrm{NaOH}$ was added at $56^{\circ} \mathrm{C}$ for $5 \mathrm{~min} .2 \mathrm{ml}$ of cold $15 \%$ TCA was added and the precipitate allowed to stand overnight at $4^{\circ} \mathrm{C}$, centrifuged at $2000 \mathrm{rpm}$ for $15 \mathrm{~min}$, the precipitate washed three times with $5-\mathrm{ml}$ portions of $10 \%$ TCA, and dissolved and counted as described above.

Each determination of incorporation of radioactive precursors was performed with triplicate tubes, and where feasible in quadruplicate.

MoRPhology. The percentage of cells which were morphologically altered (per cent transformation) was determined by the method of Hirschhorn (18).

Materials. EACA (Calbiochem Corp. Los Angeles, Calif.) was dissolved in (MEMS) and added in $0.2 \mathrm{ml}$ portions before the addition of PHA to obtain the indicated final concentrations. Cycloheximide (Actidione, Upjohn Co., 


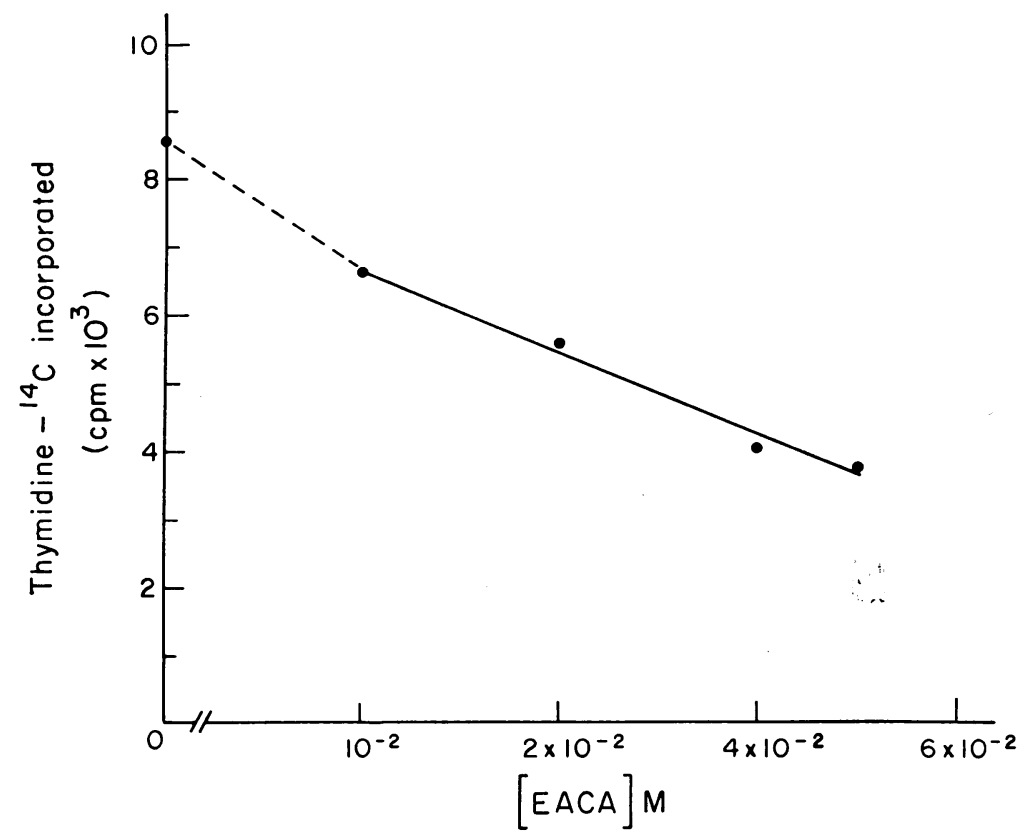

FIgURE 1 Inhibitory effect of EACA on the stimulation of RNA synthesis by PHA in human peripheral blood lymphocytes in vitro. Incorporation of thymidine ${ }^{14} \mathrm{C}$ into acid precipitable counts from 24 to $48 \mathrm{hr}$ after onset of culture was measured. For details of procedure see Methods.

Kalamazoo, Mich.) was added to obtain a final concentration of $25 \mu \mathrm{g} / \mathrm{ml}$. The optimum stimulatory concentration of each batch lot of PHA-P (Difco Laboratories, Inc., Detroit, Mich.) was determined by measuring thymidine $-{ }^{14} \mathrm{C}$ incorporation $24-48 \mathrm{hr}$ after addition. All components of the culture media were obtained from Grand Island Biological Co., Berkeley, Calif., all radioactive chemicals, from New England Nuclear Corp., Boston, Mass. Trasylol was obtained from FBA Medical Research Division of Metachem Inc., New York, AMCHA (4-aminomethyl cyclohexane carboxylic acid) was obtained from Daiichi Seyaku Co. Ltd., Tokyo, Japan. Both of these compounds were obtained through the courtesy of Dr. Fritz Beller. TAME and TPCK were obtained from Mann Research Lab., and TLCK from Calbiochem Co.

TABLE I

The Effect of EACA upon Total Cell Counts and Cellular Viability of Cultured Human Peripheral Blood Lymphocytes

\begin{tabular}{|c|c|c|c|c|c|c|}
\hline \multirow[b]{2}{*}{$\begin{array}{c}\text { Concn. of } \\
\text { EACA }\end{array}$} & \multicolumn{2}{|c|}{$0 \mathrm{hr}$} & \multicolumn{2}{|c|}{$24 \mathrm{hr}$} & \multicolumn{2}{|c|}{$48 \mathrm{hr}$} \\
\hline & $\begin{array}{l}\text { Cell } \\
\text { count }\end{array}$ & $\begin{array}{c}\% \text { non- } \\
\text { viable }\end{array}$ & $\begin{array}{l}\text { Cell \% } \\
\text { count }\end{array}$ & $\begin{array}{c}\text { non- } \\
\text { viable }\end{array}$ & $\begin{array}{l}\text { Cell } \% \\
\text { count }\end{array}$ & $\begin{array}{l}\text { non- } \\
\text { viable }\end{array}$ \\
\hline 0 & $0.71 * \ddagger$ & $4.0 * \S$ & 0.54 & 11.6 & 0.46 & 6.6 \\
\hline $0.03 \mathrm{M}$ & 0.82 & 4.2 & 0.52 & 9.6 & 0.47 & 7.0 \\
\hline $0.05 \mathrm{M}$ & 0.74 & 4.3 & 0.52 & 9.5 & 0.50 & 7.3 \\
\hline
\end{tabular}

* Each value represents the average of duplicate determinations from three separate cultures.

$\ddagger$ Numbers represent cells $\times 106 / \mathrm{ml}$ of culture.

$\$$ Viability was determined by measurement of exclusion of erythrocin $B$ (see Methods).

\section{RESULTS}

EACA, at concentrations ranging from 0.05 to $0.01 \mathrm{M}$, significantly inhibited the increase in thymidine $-{ }^{14} \mathrm{C}$ incorporation induced in lymphocytes by PHA (Fig. 1). When incorporation was measured from 24 to $48 \mathrm{hr}$ after addition of PHA, $0.05 \mathrm{~m}$ EACA, in 12 separate experiments, it inhibited an average of $50.6 \pm 10.22 \%$ (SD) of the thymidine ${ }^{14} \mathrm{C}$ incorporation. Higher concentrations of EACA further reduced the PHA-induced incorporation of thymidine ${ }^{14} \mathrm{C}$ by over $90 \%$. For example, when stimulation of lymphocytes by PHA resulted in an incorporation of $10,876 \mathrm{cpm}$, compared to an incorporation of $334 \mathrm{cpm}$ by non-stimulated lymphocytes, the addition of $0.09 \mathrm{M} \mathrm{EACA}$ at $0 \mathrm{hr}$ to PHAstimulated cultures resulted in the incorporation of only $1141 \mathrm{cpm}$.

Inhibition of PHA stimulation of DNA synthesis could have resulted from a nonspecific decrease in cellular viability, rather than because of a specific inhibition by EACA of a step unique to stimulated cells. To evaluate this possibility, total cell counts were performed at 0,24 , and $48 \mathrm{hr}$ and viability as reflected by dye exclusion was measured. As seen in Table I, no dose-dependent changes were observed after addition of EACA to nonstimulated cells. However, because of the leukoagglutination produced by PHA, total cell counts and viability in stimulated cultures could not be reliably measured using standard techniques. Therefore, the total 
DNA content of the cultured cells (18) was determined at 0,24 , and $48 \mathrm{hr}$ after addition of PHA and EACA, as a measure of total cells present per culture. There was no detectable effect of EACA upon total cell number, as reflected by measurement of DNA content (Table II). Therefore, it appeared that the inhibition of PHA-induced thymidine ${ }^{-14} \mathrm{C}$ incorporation by EACA was not secondary to a grossly measurable loss of cells or alteration in cellular viability.

The possibility remained that there had been a more subtle impairment of normal cellular function, which although it did not result in cell death, did interfere with the cell's ability to increase the rate of DNA synthesis in response to PHA. Therefore, cells were preincubated at $37^{\circ} \mathrm{C}$ with varying concentrations of EACA $(0.05$ and $0.025 \mathrm{M}$ ) for $48 \mathrm{hr}$. Cells were also simply incubated as a control. At the end of $48 \mathrm{hr}$ the cells were washed twice with MEMS (with $1 \mathrm{hr}$ intervals at $37^{\circ} \mathrm{C}$ between washes) to remove EACA and their capacity to respond to PHA was measured. This was done by adding PHA and measuring DNA synthesis from 24 to $48 \mathrm{hr}$ after addition of PHA. In addition, as a positive control the capacity of the preincubated washed cells to be inhibited by EACA was also measured. Thus, after incubating cells for $48 \mathrm{hr}$ in medium alone and washing them, EACA was added to those cells simultaneously with the addition of PHA. Cells incubated with EACA and PHA simultaneously showed the expected $50 \%$ reduction of
TABLE II

Effect of EACA upon Total Cell Number in Cultures of Human Peripheral Blood Lymphocytes as Reflected by DNA Content

\begin{tabular}{|c|c|c|c|c|c|c|}
\hline \multirow{2}{*}{$\begin{array}{l}\text { Concn. } \\
\text { of } \\
\text { EACA }\end{array}$} & \multicolumn{3}{|c|}{ Control } & \multicolumn{3}{|c|}{ PHA } \\
\hline & $0 \mathrm{hr}$ & $24 \mathrm{hr}$ & $48 \mathrm{hr}$ & $0 \mathrm{hr}$ & $24 \mathrm{hr}$ & $48 \mathrm{hr}$ \\
\hline 0 & $8.03^{*}$ & 7.15 & 6.50 & 8.03 & 6.44 & 5.82 \\
\hline $0.01 \mathrm{M}$ & - & - & - & - & 6.29 & 5.77 \\
\hline $0.03 \mathrm{M}$ & - & 6.5 & 6.35 & - & 6.50 & 5.77 \\
\hline $0.05 \mathrm{M}$ & - & 6.82 & 6.41 & - & 6.24 & 5.62 \\
\hline
\end{tabular}

* Each value represents an average of 6 determinations and is expressed as $\mu \mathrm{g} \mathrm{DNA} / 10^{6}$ cells present at 0 time.

thymidine $-{ }^{14} \mathrm{C}$ incorporation at $0.05 \mathrm{M}$ EACA. In contrast, cells treated with the same concentration of EACA for the same length of time and then stimulated with PHA, incorporated thymidine as avidly as cells treated with PHA alone (Fig. 2). Since preincubation of cells with EACA did not affect their subsequent ability to respond to PHA it appeared that EACA did not irreversibly or nonspecifically damage cells. Furthermore, since the effect of EACA could be abolished by simple washing procedures, it appeared likely that the inhibitor was not tightly bound within the cell.

To study whether the inhibition by EACA represented interference with DNA synthesis alone, or was due to

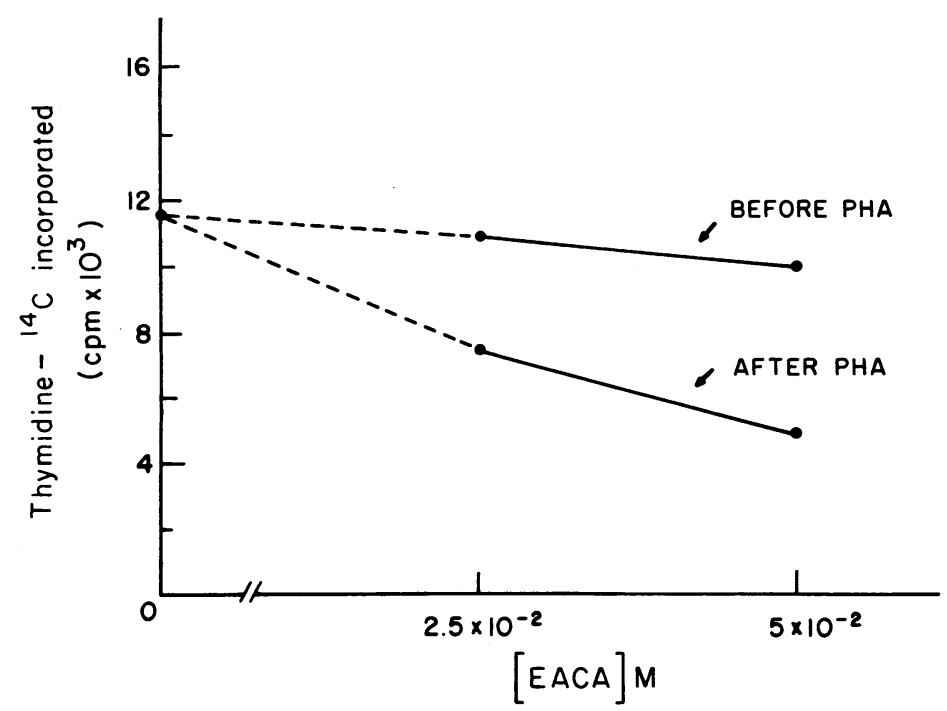

FigURE 2 Comparison of the effect of incubating lymphocytes with two concentrations of EACA for $48 \mathrm{hr}$ before the addition of PHA versus $48 \mathrm{hr}$ after the addition of PHA. Cells were incubated at $37^{\circ} \mathrm{C}$ for $48 \mathrm{hr}$ with or without EACA, washed, and PHA added. EACA was also added at this time to those incubated, washed cells that had not been in contact with EACA. Incorporation of thymidine $-{ }^{14} \mathrm{C}$ into acid-pecipitable counts was determined during the 24-48 hr after the addition of PHA. 


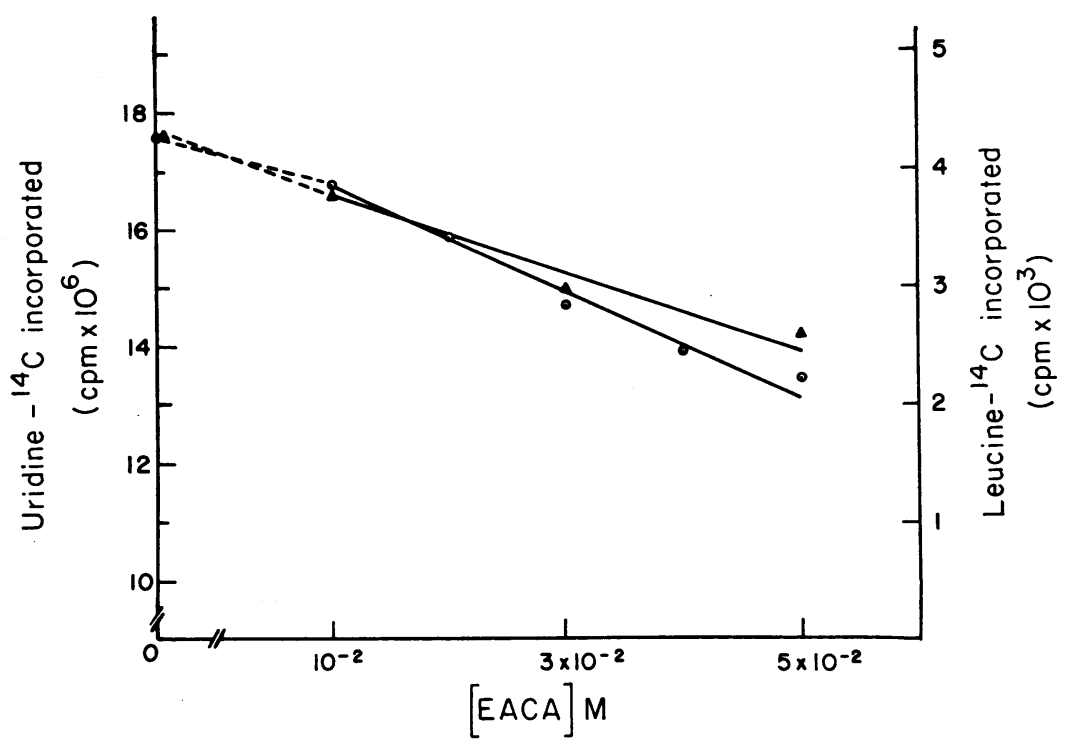

FIGURE 3 Inhibitory effect of EACA on PHA stimulation of protein and RNA synthesis in human peripheral blood lymphocytes as determined by the incorporation of leucine- ${ }^{14} \mathrm{C}$ and uridine $-{ }^{14} \mathrm{C}$. Details of procedure are given in materials and methods. $\Delta=$ leucine $-{ }^{14} \mathrm{C}$ incorporated into protein from 25 to $27 \mathrm{hr}$ after onset of culture. $\odot=$ uridine $-{ }^{14} \mathrm{C}$ incorporation into RNA from 24 to 48 hr after onset of culture.

inhibition of all aspects of lymphocyte transformation, three other parameters were measured. Incorporation of uridine $-{ }^{14} \mathrm{C}$ and leucine $-{ }^{14} \mathrm{C}$ into acid-precipitable counts was determined after $24 \mathrm{hr}$ of culture in the presence or absence of various concentrations of EACA. EACA inhibited both the PHA-induced increase of uridine- ${ }^{14} \mathrm{C}$ and of leucine $-{ }^{14} \mathrm{C}$ incorporation (Fig. 3). When rates of RNA and DNA synthesis were determined over a period of 3 days of culture, it was found that the inhibitory effect was maintained (Figs. 4 and 5). Additionally, examination of the morphologic appearance of these cells revealed that inhibition of macromolecular synthesis was paralleled by an inhibition of the morphologic alterations associated with PHA stimulation. Thus, addition of $0.05 \mathrm{~m}$ EACA inhibited $50 \%$ of the transformation induced by PHA (Table III).

Although both RNA and protein synthesis were inhibited by EACA at $24 \mathrm{hr}$, protein synthesis appeared to be inhibited to a greater extent than did RNA synthesis. Therefore, it remained possible that EACA competed with other amino acids such as lysine for transport, thereby affecting the availability of amino acids and thus affecting total protein synthesis (19). To evaluate this possible mechanism, the effect of EACA upon RNA and protein synthesis during the first $3 \mathrm{hr}$ of culture was examined. Simultaneously, the effect of a known inhibitor of protein synthesis (cycloheximide) upon RNA synthesis was also determined. Addition of EACA $(0.05 \mathrm{M})$ at the time of addition of PHA reduced $\mathrm{PHA}$-induced increases in uridine incorporation by approximately $50 \%$ (Table IV). (The slight increase of leucine- ${ }^{14} \mathrm{C}$ incorporation under these conditions could not be evaluated since it did not exceed the $\pm 5 \%$ error in duplicate determinations.) In contrast, despite the almost complete inhibition of protein synthesis by cycloheximide, no gross effect upon RNA synthesis was observed at this time interval, as previously noted by Kaye and Korner (20). Therefore, a primary interference with protein synthesis could not account for the $50 \%$ reduction in early RNA synthesis caused by EACA.

EACA has been reported to affect potassium transport (21). Thus, when EACA is taken up by muscle cells, its amine group appears to displace intracellular potassium, causing release of cation into extracellular fluid. It has been shown previously that lymphocyte transformation can be inhibited by inhibition of $\mathrm{Na}^{+}-\mathrm{K}^{+}$ transport by ouabain. This inhibition can be reversed by high concentrations of potassium in the culture medium, indicating that ouabain-sensitive $\mathrm{Na}^{+}-\mathrm{K}^{+}$transport is essential for normal lymphocyte metabolism (22). Therefore, the effect of varying potassium concentrations in the culture medium was studied. Minimum essential medium was prepared with increasing concentrations of $\mathrm{K}^{+}$, and the $\mathrm{Na}^{+}$concentration was varied to preserve the osmolarity of the media. Replicate cultures were prepared with and without $0.05 \mathrm{M} \mathrm{EACA}$ in the presence of minimal essential media containing $0.4,1,2,3$, and $4 \mathrm{mg} / \mathrm{ml}$ 




FIGURE 4 Time course of inhibition by EACA of PHA stimulation of DNA synthesis in lymphocytes, as measured by incorporation into thymidine $-{ }^{14} \mathrm{C}$ at intervals of $0-24,24-48$, and 48-72 $\mathrm{hr}$ after the addition of EACA to PHA-stimulated lymphocytes. EACA was present at $0.05 \mathrm{M}$ concentration.

of $\mathrm{KCl}$. The cell suspensions were cultured and incubated with thymidine $-{ }^{14} \mathrm{C}$ as previously described.

Increasing the concentration of potassium in the culture medium as much as 10 -fold could not reverse the inhibition of thymidine $-{ }^{14} \mathrm{C}$ incorporation produced by EACA (Table V). Thus it would appear unlikely that the effect of EACA upon lymphocyte transformation is secondary to an effect upon sodium-potassium transport.

Previous experiments have reported that EACA diminishes the antigen binding capacity of rabbit antiBSA antisera (23). Since EACA could block lymphocyte transformation by similarly blocking the initial binding and/or uptake of PHA, the binding of PHA to lymphocytes was measured. PHA was adsorbed from solution by multiple exposures to lymphocytes both in the presence and absence of EACA. The amount of PHA remaining in the supernatant was then indirectly measured by adding portions and dilutions of such supernatants to unstimulated lymphocytes. Thus, $0.2 \mathrm{ml}$ of PHA-P (of a vial diluted to $10 \mathrm{ml}$ ) was added to each of three 4-ml portions of MEMS. EACA ( $0.05 \mathrm{~m}$ final concentration) was then added to two of the portions, and the volume was adjusted in the other portion with MEMS. Portions with and without EACA were then in- cubated with pellets of $20 \times 10^{\circ}$ washed cells for $\frac{1}{2} \mathrm{hr}$ at $37^{\circ} \mathrm{C}$ in a shaking water bath. This step was repeated until a decrease in leukocyte agglutination was observed microscopically (approximately seven adsorptions). The third portion containing EACA was not placed in contact with cells but was incubated at $37^{\circ} \mathrm{C}$ during the course of adsorption. The amount of PHA left in the supernatant (e.g. not adsorbed) was then assayed by the

\section{TABLE III}

Effect of EACA on Percentage of Cells "Transformed" and Mitotic Index of PHA-Stimulated Lymphocytes

\begin{tabular}{ccc}
\hline $\begin{array}{c}\text { Concn. of } \\
\text { EACA }\end{array}$ & $\begin{array}{c}\text { Mitoses/ } \\
1000 \text { cells }\end{array}$ & $\begin{array}{c}\text { Transformed* } \\
\text { cells and } \\
\text { mitoses }\end{array}$ \\
\hline 0 & & $\%$ \\
$0.025 \mathrm{M}$ & 15 & 50 \\
$0.050 \mathrm{M}$ & 3 & 47 \\
$0.075 \mathrm{M}$ & 3 & 25 \\
\hline
\end{tabular}

* Morphologic criteria for determining cell transformation are those of Hirschhorn (18). 
capacity of three dilutions of each of the three portions to stimulate lymphocyte DNA synthesis. Thus, $0.5 \mathrm{ml}$ of the whole supernatant, and of $1: 2$ and $1: 4$ dilutions of the supernatants was then added to standard cultures and thymidine $-{ }^{14} \mathrm{C}$ incorporation measured from 24 to $48 \mathrm{hr}$ after onset of culturing. The final concentration of EACA in these cultures was $0.006 \mathrm{~m}$ or less, which is below inhibitory concentrations.

The amount of PHA absorbed by the cells was then measured by the difference in stimulatory capacity be- tween the nonabsorbed PHA containing media and that which had been passed through cells (Fig. 6). It can be seen that PHA was adsorbed by multiple incubations with cells, and furthermore, that EACA did not affect the binding of PHA under these conditions. If anything, there was slightly more stimulatory effect of the supernatants adsorbed in the absence of EACA which, if significant, could reflect either less binding or greater release of a "blastogenic factor" (24) from the lymphocytes.

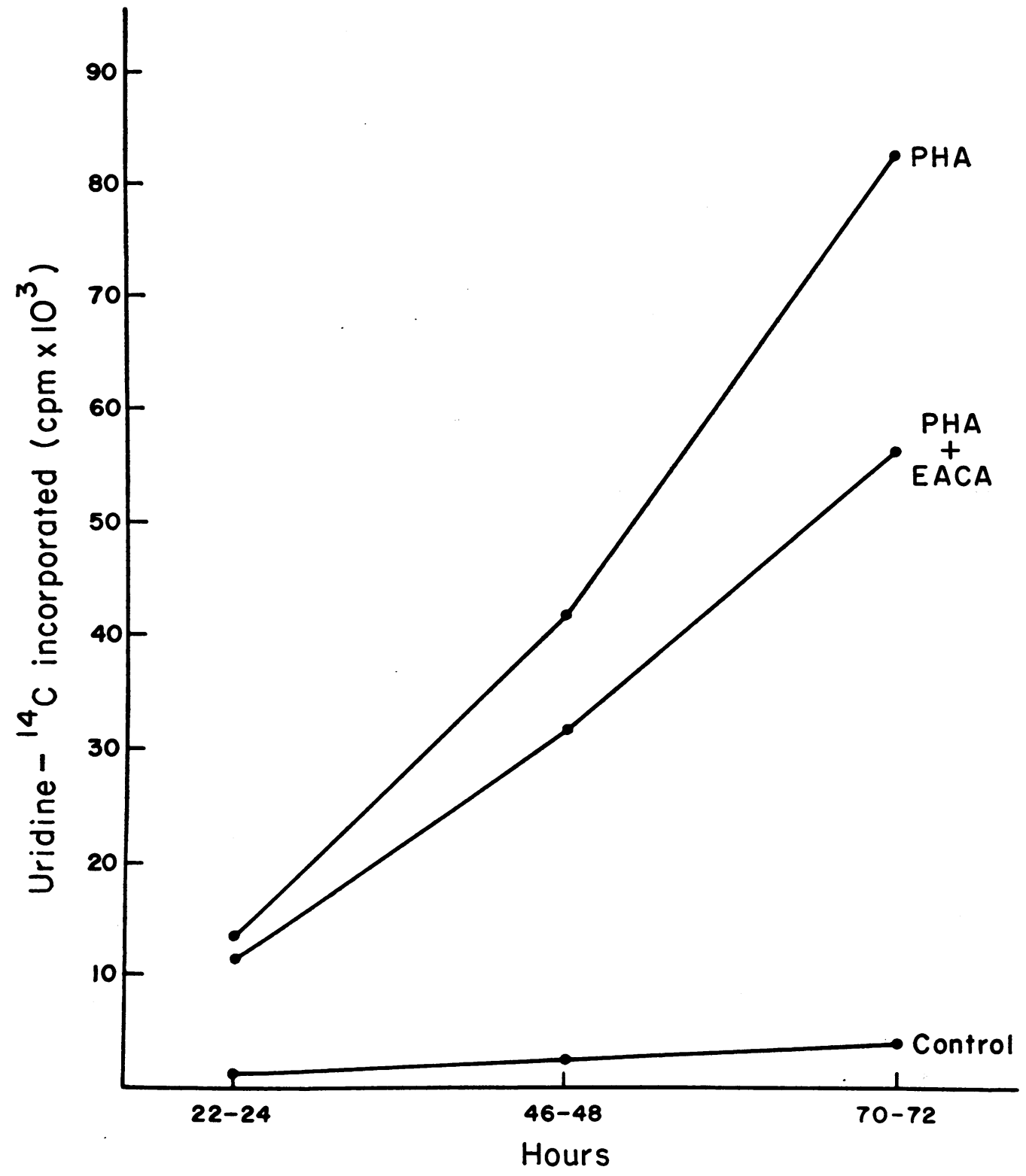

FIGURE 5 Time course of inhibition by EACA of PHA stimulation of RNA synthesis in human peripheral lymphocytes, as measured by incorporation of uridine ${ }^{-4} \mathrm{C}$ at intervals of 24,48 , and $72 \mathrm{hr}$ after the addition of EACA $(0.05 \mathrm{M})$ to PHA-stimulated lymphocytes. Uridine- ${ }^{14} \mathrm{C}$ was added for the last $2 \mathrm{hr}$ of culture. 
If EACA were to block a step specific to lymphocyte stimulation rather than to interfere with metabolic pathways necessary for normal cellular function, it would be more effective when added early, rather than late in the course of stimulation. Consequently, the effect of EACA during the first $24 \mathrm{hr}$ of culture was compared to the effect of EACA during the second $24 \mathrm{hr}$ of culture. EACA was added to PHA-stimulated cultures at 0 time, and 24 $\mathrm{hr}$ later the cells were washed as previously described, and re-incubated in fresh medium not containing EACA for another $24 \mathrm{hr}$. This wash procedure, as shown in previous experiments (Fig. 7), is sufficient to remove EACA. Simultaneously, duplicate cultures of stimulated lymphocytes were also washed at $24 \mathrm{hr}$ and then EACA was added for the second $24 \mathrm{hr}$ of culture. The presence of EACA $(0.05 \mathrm{M})$ during the first $24 \mathrm{hr}$ of culture, reduced thymidine $-{ }^{14} \mathrm{C}$ incorporation by $49.6 \%$ in PHA-stimulated cultures, whereas the same concentration of EACA, present during the second $24 \mathrm{hr}$ of culture, reduced thymidine $-{ }^{14} \mathrm{C}$ incorporation by only $5 \%$.

To further examine the role of proteolysis, the effect of other inhibitors was determined. Trasylol (25) in concentrations ranging from $2.5 \times 10^{-4} \mathrm{M}$ to $5 \times 10^{-6} \mathrm{M}$ did not have any effect upon lymphocyte stimulation. It is conceivable that trasylol, with a molecular weight of 6512 and a maximum diameter of $25 \mathrm{~A}$ did not enter the cell. AMCHA (26), which is a more potent inhibitor of plasminogen activation than EACA, did not inhibit at $5 \times 10^{-3} \mathrm{M}$. The finding that $\mathrm{AMCHA}$ and trasylol appeared to be ineffective led us to examine the effects of inhibitors of proteolysis other than those acting upon the plasminogen system. Thus we examined TLCK, an inhibitor of trypsin, and TPCK, an inhibitor of chymotrypsin. Both of these compounds inhibited lymphocyte stimulation significantly at concentrations of $10^{-5} \mathrm{M}$ as

TABLE IV

Effect of EACA upon ${ }^{14} \mathrm{C}$ Uridine and ${ }^{14} \mathrm{C}$ Leucine Incorporation during the First $3 \mathrm{hr}$ of Culture*

\begin{tabular}{|c|c|c|}
\hline & RNA & Protein \\
\hline & $\begin{array}{l}\text { Incor- } \\
\text { poration } \\
\text { of uri- } \\
\text { dine-14C }\end{array}$ & $\begin{array}{l}\text { Incor- } \\
\text { poration } \\
\text { of leu- } \\
\text { cine-14C }\end{array}$ \\
\hline & $c p m$ & $c p m$ \\
\hline (-) PHA & 16,025 & 16,418 \\
\hline (+) PHA & 36,201 & 19,635 \\
\hline$(+)$ PHA $(+)$ EACA $(0.05 \mathrm{~m})$ & 25,464 & 20,687 \\
\hline $\begin{array}{l}(+) \text { PHA (+) Cycloheximide } \\
(25 \mu \mathrm{g} / \mathrm{ml})\end{array}$ & 39,299 & 2,268 \\
\hline
\end{tabular}

* $20 \mathrm{ml}$ cultures were preincubated overnight at $37^{\circ} \mathrm{C}$ prior to addition of the above agents. $5 \mu \mathrm{Ci}$ of ${ }^{14} \mathrm{C}$ uridine or $10 \mu \mathrm{Ci}$ of ${ }^{14} \mathrm{C}$ leucine were then added and cultures harvested $3 \mathrm{hr}$ later. All additions were made at time 0 .
TABLE V

Effect of Varying Concentrations of $\mathrm{KCi}$ on the Inhibition of PHA-stimulated Lymphocytes by EACA

\begin{tabular}{cccc}
\hline $\begin{array}{c}\text { Concen- } \\
\text { tration of } \\
\text { KCL }\end{array}$ & PHA cultures & $\begin{array}{c}\text { PHA cultures } \\
\text { with 0.05 M } \\
\text { EACA added }\end{array}$ & $\begin{array}{c}\text { Control } \\
\text { cultures }\end{array}$ \\
\hline$m g / m l$ & $c p m^{*}$ & $c p m$ & $c p m$ \\
0.4 & $26,406 \ddagger$ & 11,624 & 213 \\
1.0 & 25,649 & 9,880 & 383 \\
2.0 & 24,234 & 10,195 & 369 \\
3.0 & 22,009 & 11,329 & 265 \\
4.0 & 22,204 & 5,664 & 236
\end{tabular}

* Thymidine- ${ }^{-14} \mathrm{C}$ incorporated into DNA from 24 to $48 \mathrm{hr}$ in culture.

$\ddagger$ Each value represents an average of three determinations.

measured by thymidine $-{ }^{14} \mathrm{C}$ incorporation (Fig. 8). TAME, which also contains the tosyl group, but is only a weak competitive inhibitor of trypsin, was only effective at concentrations of $5 \times 10^{-3} \mathrm{M}$, thus suggesting that inhibition was not related to any effect of tosyl-containing compounds but was related to their activity as enzyme inhibitors.

\section{DISCUSSION}

We have demonstrated an inhibition of PHA-induced lymphocyte transformation by addition of EACA, TLCK, TPCK, and TAME. However, the biological relevance of the inhibition of lymphocyte transformation by an agent is dependent upon the mechanism by which such inhibition occurs. A number of obvious causes, therefore, have to be considered before interpreting the significance of inhibition. First, apparent inhibtion of transformation might simply reflect a killing of the responding cell. We have examined this possibility for EACA and have found no gross signs of toxicity as reflected by alterations in cell viability, as measured by dye exclusion, or by alterations in cell number, as measured by DNA content. However, changes in these parameters require either actual cell lysis or a major alteration in cellular permeability in order to be detected. Therefore, a means of detecting a more subtle, but permanent interference with cellular function was sought. The capacity of these cells to repond to PHA after preincubation with EACA was found to be unimpaired, indicating that no permanent nonspecific cell damage had occurred. Secondly, inhibition could simply reflect a block in some step specific to the incorporation of the precursor being used to measure macromolecular synthesis as a function of transformation. This was considered unlikely since inhibition by EACA could be demonstrated using several parameters of stimulation: RNA, DNA, and protein synthesis as well as morphologic alterations. 


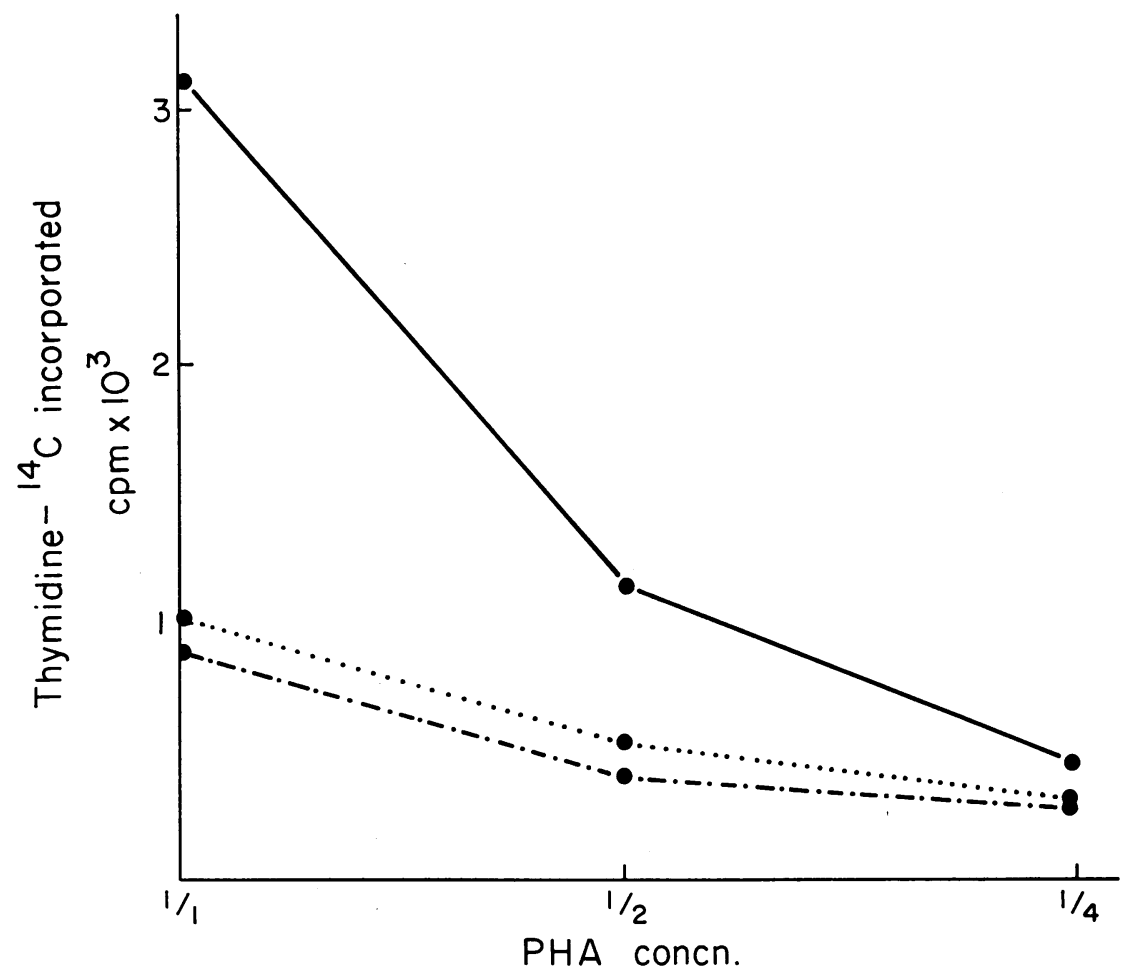

FIGURE 6 The effect of EACA on the binding of PHA to human peripheral blood lymphocytes. Several portions of lymphocytes were incubated serially with PHA in the presence or absence of EACA. Portions of the supernates, or of $\frac{1}{2}$ and $\frac{1}{4}$ dilutions, were then added to lymphocytes and the capacity to cause incorporation of thymidine $-{ }^{14} \mathrm{C}$ from 24 to $48 \mathrm{hr}$ after addition was measured. For complete details, see text. - $\longrightarrow$, untreated $\mathrm{PHA}$ solution; $-\cdot-\cdot-$, , PHA solution adsorbed with lymphocytes; $\cdots$, PHA solution adsorbed with lymphocytes in the presence of EACA.

The work of others has suggested several mechanisms whereby EACA might cause inhibition of lymphocyte transformation. Thus, it has been shown that EACA affects sodium-potassium transport (21) and that interference with such transport by ouabain interferes with lymphocyte transformation (22). We have found no evidence for such an action by EACA in inhibiting lymphocyte transformation, since it was not reversible by raising the potassium concentration. Theoretically, EACA also could inhibit by competing with amino acid transport. Such interference would produce a relative deficit of amino acids with subsequent decline of protein synthesis (19). However, the data indicate that EACA does not primarily interfere with protein synthesis, since this does not decrease until after the diminution of RNA synthesis. Lastly, we have also shown that EACA does not interfere with the binding of PHA to the lymphocytes.

From the experimental evidence it would appear that EACA clearly interfered with an early event in lymphocyte stimulation, since its later addition during stimulation was practically without effect. Additionally, it was found that other inhibitors of proteolysis such as TLCK,
TPCK, and TAME also inhibited lymphocyte transformation. We have therefore considered the possibility that proteolysis plays a role in bringing about the early alterations of macromolecular synthesis accompanying lymphocyte stimulation and that EACA acts by inhibiting such proteolysis.

Consideration of the hypothesis that proteolysis is important in lymphocyte transformation has been stimulated both by our own findings and by some of the current views as to possible mechanisms of transcriptional controls. We have previously found that shortly after. addition of PHA to lymphocytes, several alterations occur: there is an increase in endocytosis accompanied by a subcellular redistribution of acid hydrolases (6) and an increase in the capacity of the nuclei to prime for RNA synthesis (template capacity) (4). Previous evidence suggests that in the presence of excess RNA polymerase, this in vitro increase in RNA synthesis by isolated nucleoprotein reflects an increase in actual DNA sites available for transcription (27), rather than increased synthesis at previously available sites, although the nature of the increased RNA which is synthesized under these particular 
conditions has not, as yet, been determined. It has been suggested that the availability of such sites on the DNA for transcription is restricted by the presence or absence of proteins, nonhistone as well as histone. The experimental evidence for such views has recently been reviewed extensively by Georgiev (28). Control of available sites would then operate either in determining the state of differentiation of the cell or in modulating gene transcription within the framework of such differentiation. Such modulation of transcription (in addition to possible control by multiple forms of RNA polymerase; factors associated with that enzyme, etc.) (29) could occur through chemical alteration (30) (e.g. acetylation) or by removal of these specific proteins. In support of the latter hypothesis, it has been found that enzymatic removal of protein from nuclei and chromatin in vitro, results in increases of template capacity (5). For this finding to be biologically meaningful, some mechanism must be operative whereby a degree of specificity of proteolysis can be attained. It has become increasingly clear that in a number of biologic systems such as blood clotting, kinins, and the complement sequence, such specificity does exist, in that proteolysis is "limited." It is thus possible that a specific class of proteins is bound to those areas of the genetic material which are capable of being reversibly altered from facultative heterochromatin to euchromatin in a given cell. Specificity of proteolysis would then reside in the primary structure of the protein molecule and in the avidity of the proteases involved. Proteolysis might then provide the means for switching between two qualitatively different states of synthetic activity, as in the transformation of lymphocytes.

However, the bulk of evidence presented for such an explanation of the action of EACA is indirect. This circumstantial evidence is either correlative, in that addition of TLCK, TPCK, and TAME also cause inhibition,

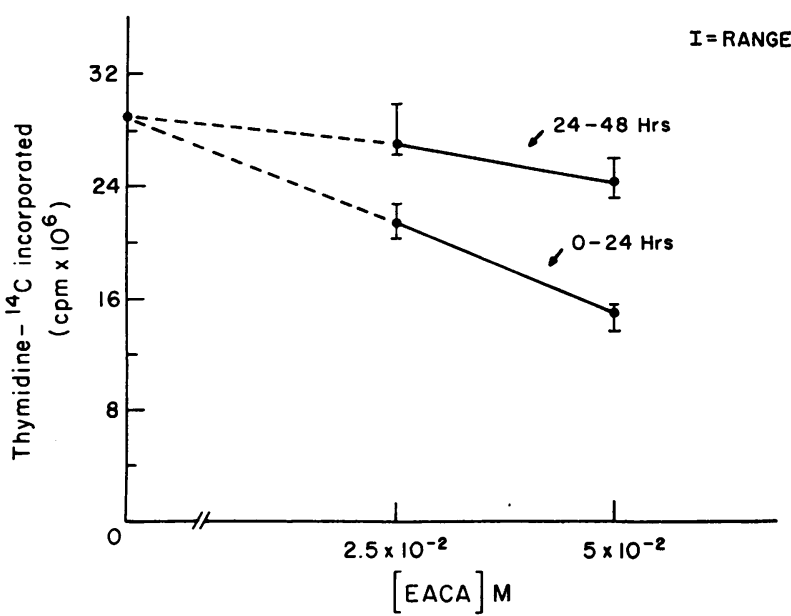

Figure 7 Effect of addition of EACA at $0 \mathrm{hr}$ and $24 \mathrm{hr}$ after the addition of PHA to human peripheral lymphocytes, as measured by incorporation of thymidine ${ }^{14} \mathrm{C}$ into DNA from 24 to $48 \mathrm{hr}$.

or it is negative in that other known actions of EACA do not appear to be of significance. In the latter case, some as yet undescribed action of EACA might be operative.

Previous findings must be considered in evaluating any mechanism for lymphocyte stimulation or its inhibition. It appears that binding of PHA to the cell membrane is the initiating factor in lymphocyte stimulation (31). If this binding is sufficient to activate the lymphocyte, the mechanism might be similar to that operative in the action of polypeptide hormones, where activation of adenyl cyclase at the cell membrane results in an increase in intracellular cyclic AMP (32). In support of this, we and others have demonstrated a twofold increase in DNA and RNA synthesis with the addition of

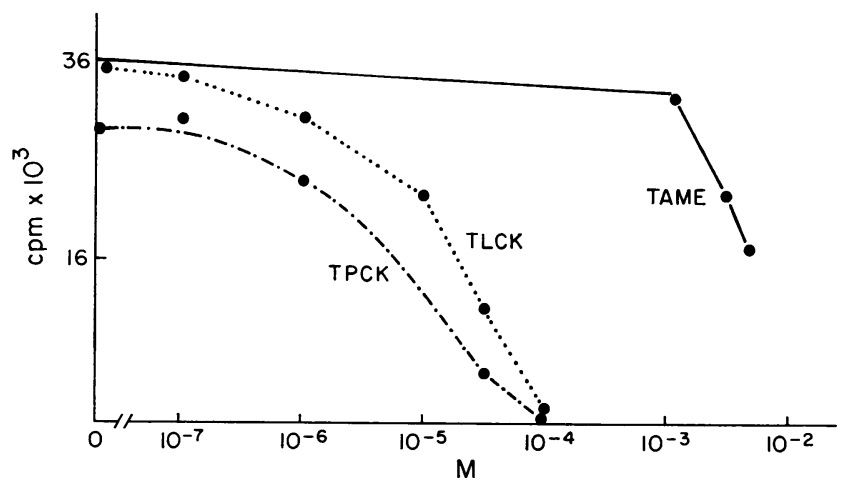

FIGURE 8 The inhibitory effect of TLCK, TPCK, and TAME upon the incorporation of thymidine- ${ }^{14} \mathrm{C}$ by PHA-stimulated human peripheral blood lymphocytes. Rates of incorporation were determined from 24 to $48 \mathrm{hr}$ after onset of culture. 
cAMP to nonstimulated lymphocytes $(33,34) .^{2}$ After exposure of the cells to PHA there also has been reported a marked increase in acetylation of histones (35), an increase in nuclear phosphoprotein turnover (36), an increase in availability of binding sites on the nucleoprotein for acridine orange $(37,38)$, and actinomycin D (39), as well as an increased capacity of the DNA to act as template for RNA synthesis (4). In addition to these alterations (all suggestive of control of lymphocyte stimulation at the transcriptional level) a change from wastage of ribosome subunits to conservation (40) has been described, suggesting control at the level of ribosomes or of translation. Since cyclic AMP acts in many tissues to augment kinases of various sorts, it is conceivable that activation by cyclic AMP of a coordinate group of enzymes, including a proteolytic system, could provide a unifying mechanism to produce all of the previously described early alterations after lymphocyte stimulation. However, it remains to be demonstrated that a proteolytic system exists in the lymphocyte which is active upon a suitable substrate, which is also activated coincidently with stimulation of the lymphocyte and which can be inhibited by EACA. Finally, from the available evidence, inhibition of proteolysis appears to be the most tenable explanation for the observed inhibition of lymphocyte transformation by EACA, TLCK, TPCK, and TAME.

\section{ACKNOWLEDGMENTS}

This work was supported by grants from the National Institutes of Health (AM 11949), and the New York Heart Association.

${ }^{2}$ Handmaker, S. D., personal communication.

\section{REFERENCES}

1. Ling, N. R. 1968. Lymphocyte Stimulation. North Holland Publishing Co., Amsterdam, Netherlands. 156.

2. Elves, M. W. 1966. The Lymphocyte. J. B. Lippincott Co., Philadelphia, $\mathrm{Pa}$.

3. Naspitz, C. K., and M. Richter. 1968. The action of phytohemagglutinin in vivo and in vitro, a review. Progr. Allergy. 12: 1 .

4. Hirschhorn, R., W. Troll, G. Brittinger, and G. Weissmann. 1969. Template activity of nuclei from stimulated lymphocytes. Nature (London). 222: 1247.

5. Allfrey, V. G., F. C. Littau, and A. E. Mirsky. 1963. On the role of histones in regulating ribonucleic acid synthesis in the cell nucleus. Proc. Nat. Acad. Sci. U.S.A. 49: 414 .

6. Hirschhorn, R., G. Brittinger, K. Hirschhorn, and G. Weissmann. 1968. Studies on lysosomes XII. Redistribution of acid hydrolases in human lymphocytes stimulated by phytohemagglutinin. J. Cell Biol. 37: 412 .

7. Hirschhorn, K., and R. Hirschhorn. 1965. Role of lysosomes in the lymphocyte response. Lancet. 1: 1046.

8. Allison, A. C., and L. Mallucci. 1964. Lysosomes in dividing cells with special reference to lymphocytes. Lancet. 11: 1371 .
9. Alkjaersig, N., A. P. Fletcher, and S. Sherry. 1959. EACA an inhibitor of plasminogen activation. J. Biol. Chem. 234: 832.

10. McNicol, G. P., and A. S. Douglas. 1964. EACA and other inhibitors of fibrinolysis. Brit. Med. Bull. 20: 233.

11. Ambrus, C. M., J. L. Ambrus, H. B. Lassman, and I. B. Mink. 1968. Studies in the mechanism of action of inhibitors of the fibrinolysis system. Ann. N. Y. Acad. Sci. 146: 430.

12. Ali, S. Y. 1964. The degradation of cartilage matrix by an intracellular protease. Biochem. J. 93: 611.

13. Weissmann, G., and I. Spilberg. 1968. Breakdown of cartilage protein-polysaccharide by lysosomes. Arthritis Rheum. 11: 162.

14. Davies, P., K. Krakauer, and G. Weissmann. 1970. Manuscript in preparation.

15. Brittinger, G., R. Hirschhorn, S. D. Douglas, and G. Weissmann. 1968. Studies on lysosomes XI. Characterization of a hydrolase-rich fraction from human lymphocytes. J. Cell Biol. 37 : 394.

16. Burton, K. 1956. A study of the condition and mechanism of the diphenylamine reaction for the colorometric estimation of deoxyribonucleic acid. Biochem. J. 62: 315 .

17. Tedesco, T. A., and W. J. Mellman. 1967. Desoxyribonucleic acid assay as a measure of cell numbers in preparations from monolayer cell cultures and blood leucocytes. Exp. Cell Res. 45: 230.

18. Hirschhorn, K. 1965. Method for studying lymphocyte interaction and other immunologic and cytogenetic studies of human lymphocytes. In: Histocompatability Testing, Nat. Acad. Sci. Nat. Res. Council. 177.

19. Maden, B. E. H. 1969. Effects of lysine or valine starvation on ribosome subunit balance in HeLa cells. Nature (London). 224: 1203.

20. Kay, J. E., and A. Korner. 1966. Effect of cycloheximide on protein and ribonucleic acid synthesis in cultured human lymphocytes. Biochem. J. 100: 815.

21. Carrol, H. J., and D. A. Tice. 1966. The effect of epsilon amino caproic acid upon potassium metabolism in the dog. Metab. Clin. Exp. 15: 449.

22. Quastel, M. R., and J. G. Kaplan. 1968. Inhibition by ouabain of human lymphocyte transformation induced by phytohemagglutinin in vitro. Science (Washington). 219: 198.

23. Wold, R. T., R. T. Reid, and R. S. Farr. 1967. The effect of epsilon amino caproic acid on antigen antibody reaction. J. Immunol. 99: 797.

24. Maini, R. N., A. D. M. Bryceson, R. A. Wolstencroft, and D. C. Dumonde. 1969. Lymphocyte mitogenic factor in man. Nature (London). 224: 43.

25. Fritz, H., I. Trantschold, H. Haendle, and E. Werte. 1968. Chemistry and biochemistry of protein inhibitors from mammalian tissues. Ann. N. Y. Acad. Sci. 146: 400.

26. Okamoto, S., S. Oshiba, H. Mihara, and O. Okamoto. 1968. Synthetic inhibitors of fibrinolysis; in vitro and in vivo mode of action. Ann. N. Y. Acad. Sci. 145: 414.

27. Bonner, J., M. E. Dahmus, D. Fambrough, R. C. Huang, K. Marushiga, and D. Y. H. Tuan. 1968. The biology of isolated chromatin. Science (Washington). 159: 47.

28. Georgiev, G. P. 1969. Histones and the control of gene action. Annu. Rev. Genet. 3: 155.

29. Allfrey, V. G. 1970. Changes in chromosomal proteins at times of gene activation. Fed. Proc. 29(4): 1447.

30. Burgess, R. R., and A. A. Travers. 1970. Eschericia coli RNA polymerase : purification, subunit structure and factor requirements. Fed. Proc. 29(3): 1164. 
31. Lindahl-Kiessling, K., and R. D. A. Peterson. 1969. The mechanism of phytohemagglutinin (PHA) action. III. Stimulation of lymphocytes by allogeneic lymphocytes in phytohemagglutinin. Exp. Cell Res. 55: 85.

32. Robison, G. A., R. W. Butcher, and E. W. Sutherland. 1968. Cyclic AMP. Ann. Rev. Biochem. 37: 149.

33. Hirschhorn, R., J. Grossman, and G. Weissmann. 19,0. Effect of cyclic $3^{\prime}, 5^{\prime}$ adenosine monophosphate and theophylline on lymphocyte transformation. Proc. Soc. Exp. Biol. Med. 133: 1361.

34. Smith, J. W., A. L. Steiner, and C. W. Parker. 1970. Early effects of phytohemagglutinin (PHA) on lymphocyte cyclic AMP levels. Fed. Proc., 29: 369 (Abst.)

35. Pogo, B. G. T., V. G. Allfrey, and A. E. Mirsky. 1966. RNA synthesis and histone acetylation during the course of gene activation in lymphocytes. Proc. Nat. Acad. Sci. U.S.A., $55: 805$.

36. Kleinsmith, L. J., V. G. Allfrey, and A. E. Mirsky.
1966. Phosphorylation of nuclear protein early in the course of gene activation in lymphoctyes. Science (Washington). $154: 780$.

37. Killander, D., and R. Rigler. 1965. Initial changes of deoxyribonucleoprotein and synthesis of nucleic acid in phytohemagglutinine-stimulated human leucocytes in vitro. Exp. Cell Res. 39: 701.

38. Killander, D., and R. Rigler. 1969. Activation of deoxyribonucleoprotein in human leucocytes stimulated by phytohemagglutinin II. Structural changes of deoxyribonucleoprotein and synthesis of RNA Exp. Cell Res. 54: 171.

39. Ringertz, N. R., Z. Darzynkiewicz, and L. Bolund. 1969. Actinomycin binding properties of stimulated human lymphocytes. Exp. Cell Res. 56: 411.

40. Cooper, H. L. 1969. Ribosomal ribonucleic acid production and growth regulation in human lymphocytes. $J$. Biol. Chem. 244: 1946. 